\title{
Ciri-ciri dan Jenis Adverbia Pewatas dalam Bahasa Indonesia
}

\author{
Mujid Farihul Amin \\ Fakultas Ilmu Budaya, Universiutas Diponegoro \\ moejid70@gmail.com
}

\begin{abstract}
The type of borderline adverbs in Indonesian is not just two - as stated in the Indonesian Book Language Book (1993) -, but four. The four types of border adverbs are verb-limiting adverbs, adjective adjuster adverbs, nomina-limiting adverbs, and numerical delimiter adverbs. Although in the discussion we can see a barrier adverb that can be used more than one type, but it will not weaken the description that has been obtained.
\end{abstract}

Keywords: borderline adverbs, Indonesian.

\section{Intisari}

Jenis adverbia pewatas dalam bahasa Indonesia bukan hanya dua - seperti dinyatakan dalam Tata Bahasa Buku Bahasa Indonesia (1993) - , melainkan empat. Keempat jenis adverbia pewatas itu adalah adverbia pewatas verba, adverbia pewatas adjektiva, adverbia pewatas nomina, dan adverbia pewatas numeralia. Meskipun dalam pembahasan dapat dilihat adanya adverbia pewatas yang dapat dipakai lebih dari satu jenis, namun hal itu tidak akan melemahkan deskripsi yang telah diperoleh.

Kata Kunci: adverbial pewatas, bahasa Indonesia.

\section{Pendahuluan}

Kelas kata mempunyai peranan yang sangat penting dalam tata bahasa suatu bahasa. Hal ini dapat kita maklumi karena kata merupakan satuan formal pembentuk satuan (formal) yang lebih besar yaitu frasa (Surono, $1990: 6$ ). Analisis frasa tidak akan tuntas tanpa membicarakan unsur-unsur pembentuknya yaitu kata.

Dalam bahasa Indonesia, kita mengenal adanya berbagai kategori/ kelas kata. Pendapat para ahli bahasa mengenai kelas kata dalam bahasa Indonesia berbeda-beda. Yang dipakai sebagai acuan dalam tulisan ini adalah Tata Bahasa Buku Bahasa Indonesia (1993) ditambah pendapat Harimurti Kridalaksana dalam buku Kelas Kata dalam Bahasa Indonesia (1986).

Dalam Tata Bahasa Buku Bahasa Indonesia (1993), kelas kata dalam bahasa Indonesia dibagi menjadi lima kategori. Kelima kategori itu adalah Verba, Abjektiva, Adverbia, Nomina/Pronomina/Numeralia, dan Kata Tugas. Dalam tulisan ini, yang akan dibahas secara khusus adalah adverbia dalam kaitannya dengan makna relasional 
adverbia.

Berkaitan dengan makna relasional adverbia pada satuan frasa, ada adverbia yang secara semantis bergantung pada satuan leksikal lain. Ini yang disebut adverbia pewatas. Penjelasan mengenai adverbia pewatas dan jenis-jenisnya dalam bahasa Indonesia, secara deskriptif akan diuraikan pada tulisan berikut. Permasalahan yang akan dibahas dalam tulisan ini mencakup tiga hal, yaitu batasan dan ciri adverbia dalam bahasa Indonesia, batasan dan ciri adverbia pewatas dalam bahasa Indonesia, dan jenis-jenis adverbia pewatas dalam bahasa Indonesia.

\section{Metode Penelitian}

Model penelitian ini adalah penelitian deskriptif analitis. Arikunto (2010: 3) mengatakan model penelitian deskriptif merupakan penelitian yang benar-benar hanya memaparkan apa yang terdapat atau terjadi dalam sebuah kancah lapangan, atau wilayah tertentu. Adapun metode yang digunakan dalam penelitian ini mencakup tiga tahapan strategis yaitu pengumpulan data, analisis data, dan penyajian hasil analisis data (Sudaryanto, 1991).

\section{Batasan dan Ciri Adverbia dalam Bahasa Indonesia}

Adverbia adalah kata yang digunakan untuk menerangkan unsur atau bagian kalimat yang berfungsi sebagai predikat, baik yang berupa verba, adjektiva, nomina, maupun numeralia (TBBI, 1993 : 218). Sebagai contoh, perhatikan pemakaian kata sudah, sangat, kurang, hanya, dan masih pada kalimat-kalimat berikut.

(1) Ayah sudah pergi.

(2) Anak itu sangat pandai.

(3) Air itu kurang panas.

(4) Pacar say a hanya Rina.

(5) Anaknya masih satu.

Dalam kalimat (1) kata sudah adalah adverbia yang menerangkan verba pergi; dalam kalimat (2) dan (3) kata sangat dan kurang adalah adverbia yang menerangkan adjektif pandai dan panas. Demikian pula dalam kalimat (4) kata hanya adalah adverbia yang menerangkan nomina Rina. Adapun kata masih dalam kalimat (5) merupakan adverbia yang menerangkan numeralia satu.

Di samping menjelaskan bagian kalimat yang berfungsi sebagai predikat, seperti 
yang dicontohkan dalam kalimat (1) - (5), adverbia juga dipakai untuk menjelaskan seluruh klausa atau kalimat. Pada contoh berikut terlihat bahwa mungkin adalah adverbia yang menerangkan klausa dia pergi.

(6) Mungkin dia pergi.

Dengan batasan seperti tersebut di atas, orang sering mengacaukan pengertian adverbia dengan keterangan atau adverbial. Perbedaan yang nyata antara adverbia dengan adverbial adalah, kalau adverbia merupakan istilah yang dipakai untuk kategori atau kelas kata sedangkan adverbial merupakan istilah yang dipakai untuk fungsi sintaktis. Perbedaan itu dapat dilihat pada pemakaian kata besok dan segera pada kalimat berikut.

(7) Ayah datang besok.

(8) Saya segera berangkat.

Kata besok pada kalimat (8) termasuk dalam kategori nomina (bukan adverbia). Tetapi, jika dilihat dari fungsinya kata besok merupakan adverbial atau keterangan (keterangan waktu) Pada kalimat (8), kata segera berfungsi sebagai adverbial dan kategori atau kelas katanya adalah adverbia.

Dengan contoh-contoh di atas, perbedaan antara adverbia dan adverbial sudah terlihat jelas. Uraian selanjutnya akan lebih meng-khususkan pada adverbia pewatas dan jenis-jenisnya dalam bahasa In-donesia .

\section{Batasan dan Ciri Adverbia Pewatas}

Adverbia bisa ditinjau dari segi maknanya dalam kaitannya dengan unsur yang lain pada suatu struktur. Hubungan makna adverbia dengan unsur lain dalam tulisan ini disebut makna relasional adverbia (mengikuti penyebutan dalam Tata Bahasa Buku Bahasa Indonesia, 1993 : 224). Makna relasional adverbia yang akan diamati dalam tulisan ini adalah makna relasional adverbia dalam satuan frasa.

Dalam kaitannya dengan makna relasional adverbia pada satuan frasa, ada adverbia yang secara semantis bergantung pada satuan leksikal lain. Jadi, keberadaan adverbia tersebut di dalam suatu satuan frasa berkaitan dengan konstituen lain. Adverbia yang keberadaannya secara semantis bergantung pada satuan leksikal lain dan berfungsi mewatasi satuan leksikal lain disebut adverbia pewatas. 
Jadi, dalam suatu konstruksi frasa yang salah satu konstituennya adalah adverbia, maka adverbia itu berfungsi sebagai pewatas, sedangkan konstituen yang lain adalah inti. Inti ini bisa berupa nomina, verba, adjektiva, maupun numeralia. Untuk memperjelas pernyataan di atas, perhatikan contoh (9) - (16) berikut.

(9) Ibu Tono bukan guru.

(10) Ayah saya hanya petani.

(11) Akhir-akhir ini saya jarang pergi.

(12) Dia baru membeli mobil.

(13) Luka-lukanya sangat parah.

(14) Saya agak letih sore ini.

(15) Adik saya memang dua.

(16) Saudaranya mungkin lima.

Kata guru dan petani adalah inti sedangkan bukan dan hanya menjadi pewatasnya. Begitu juga pada frasa jarang pergi (11), baru membeli (12), sangat parah (13), agak letih (14), memang dua (15), dan mungkin lima (16), kata pergi, membeli, parah, letih, memang, dan lima masing-masing sebagai inti; sedangkan kata jarang, baru, sangat, agak, memang, dan mungkin masing-masing sebagai pewatasnya.

\section{Jenis-Jenis Adverbia Pewatas dalam Bahasa Indonesia}

Jenis-jenis adverbia pewatas yang ada dalam bahasa Indonesia dalam hubungannya dengan pewatas-inti sangat tergantung dari kategori pengisi intinya. Berdasarkan kategori pengisi inti, adverbia pewatas dapat dibedakan menjadi adverbia pewatas verba, adverbia pewatas adjektiva, adverbia pewatas nomina, dan adverbia pewatas numeralia.

Jadi, bukan hanya ada dua adverbia pewatas dalam bahasa Indonesia (adverbia pewatas adjektiva dan adverbia pewatas verba) seperti yang disebutkan dalam Tata Bahasa Baku Bahasa Indonesia (1993: 224). Keterangan selengkapnya keempat adverbia pewatas di atas dapat dilihat pada uraian berikut.

\section{Adverbia Pewatas Verba}

Adverbia pewatas verba adalah adverbia yang mewatasi suatu verba. Jadi, dalam konstruksi pewatas-inti, sebagai pewatasnya adalah adverbia sedang intinya adalah verba. Perhatikan contoh berikut. 
(17) Tuti pernah berjalan satu hari satu malam.

(18) Tiap hari kerjanya hanya melamun.

(19) Ibu selalu membeli oleh-oleh setiap pergi ke pasar.

Pada frasa pernah berjalan (contoh (17)), kata pernah yang merupakan adverbia sebagai pewatas dan kata berjalan yang merupakan verba sebagai inti. Demikian juga pada frasa hanya merenung (contoh (18)) dan selalu membeli (contoh (19)), verba merenung dan membeli masing-masing sebagai inti dan adverbia hanya dan selalu masing-masing sebagai pewatas.

Selain adverbia pernah, hanya, dan selalu, adverbia lain yang bisa bertindak sebagai adverbia pewatas verba masih banyak seperti pada contoh-contoh berikut.

$\begin{array}{lll}\text { (20) hampir } & \text { baru } & \text { paling } \\ \text { jarang } & \text { senantiasa } & \text { belum } \\ \text { kadang-kadang } & \text { sudah } & \text { boleh } \\ \text { sering } & \text { akan } & \text { cuma } \\ \text { mungkin } & \text { sedang } & \text { dapat } \\ \text { selalu } & \text { nyaris } & \text { memang } \\ \text { segera } & \text { tentu } & \text { saling } \\ \text { saja } & \text { telah } & \text { bisa } \\ \text { harus } & \text { tidak } & \text { juga } \\ \text { masih } & \text { jangan } & \text { justru } \\ \text { pernah } & \text { sempat } & \text { ingin }\end{array}$

Dari segi letak strukturnya dapat diamati perilaku adverbia pewatas verba ada yang (a) selalu mendahului kata yang diterangkan, seperti hampir, pernah, akan, dan harus (contoh (21)); (b) selalu mengikuti kata yang diterangkan, seperti saja (contoh (22)); (c) dapat mendahului atau mengikuti kata yang diterangkan, seperti juga, segera, selalu dan kadang-kadang (contoh (23)).

(21) hampir menabrak * menabrak hampir akan membuat * membuat akan

(22) menangis saja pernah berjalan

* berjalan pernah

harus berbicara

* berbicara harus 
* saja menangis

(23) juga membeli

selalu pergi

membeli juga

pergi selalu

segera pergi

kadang-kadang berangkat

pergi segera

berangkat kadang-kadang

Selain mempunyai perilaku seperti tersebut di atas, adverbia pewatas verba juga dapat merupakan satuan tunggal pembentuk kalimat, sehingga dapat digunakan sebagai jawaban singkat atas suatu pertanyaan. Perhatikan contoh berikut.

(24) a. Apakah dia pernah berkunjung ke rumahmu ?

b. Pernah.

(25) a. Apakah kamu bisa mengerjakan semua soal ?

b. Bisa.

\section{Adverbia Pewatas Adjektiva}

Adverbia pewatas adjektiva adalah adverbia yang mewatasi suatu adjektiva. Jadi, dalam konstruksi pewatas-inti, sebagai intinya adalah adjektiva dan sebagai pewatasnya adalah adverbia. Untuk lebih jelasnya perhatikan contoh berikut.

(26) Saya agak cemas.

(27) Badannya sangat panas.

(28) Rumahnya indah sekali.

Pada frasa agak cemas (contoh (26)), adverbia agak sebagai pewatas dan adjektiva cemas sebagai inti. Begitu juga pada frasa sangat panas (contoh (27)) dan indah sekali (contoh (28)), sebagai intinya adalah adjektiva panas dan indah, sedangkan pewatasnya adalah adverbia sangat dan sekali.

Di samping adverbia agak, sangat, dan sekali ada adverbia lain yang bisa berfungsi sebagai pewatas adjektiva. Adverbia itu adalah sebagai berikut.

(29) begitu masih saling

kurang

amat makin

lebih

begini

tidak

nian

pernah

sudah

benar

$\mathrm{J}^{\mathrm{u}} \mathrm{g}^{\mathrm{a}}$

pula 
sering

Dari segi posisinya dapat diamati perilaku adverbia pewatas adjektiva ada yang (a) selalu mendahului kata yang diterangkan, seperti sangat, agak, kurang, dan paling (contoh (30)); (b) selalu mengikuti kata yang diterangkan, seperti nian, pula, dan sekali (contoh (31)); (c) dapat mendahului atau mengikuti kata yang diterangkan, seperti begitu, amat, dan juga (contoh (32)).

(30) sangat lelah

*lelah sangat

agak besar

* besar agak

(31) cantik nian

*nian cantik

tampan sekali

*sekali tampan

(32) amat mahal

mahal amat kurang bersih

* bersih kurang

paling baik

* baik paling

jelek pula

* pula jelek

sedih juga juga sedih

Selain mempunyai perilaku seperti tersebut di atas, adverbia pewatas adjektiva ada yang bisa digunakan sebagai jawaban singkat atas suatu pertanyaan ada yang tidak. Perhatikan contoh berikut.

(33) a. Apakah sakitnya sudah sembuh ?

b. * Sudah.

(34) a. Apa kamu sangat lelah ?

b. * Sangat.

\section{Adverbia Pewatas Nomina}

Adverbia pewatas nomina adalah adverbia yang berfungsi sebagai pewatas nomina. Jadi, dalam sebuah konstruksi frasa sebagai intinya adalah nomina sedangkan pewatasnya adalah adverbia. Perhatikan contoh-contoh berikut.

(35) Ayah Budi hanya petani.

(36) Tetangga saya bukan sopir. 
(37) Yang bisa mengerjakan cuma Budi.

Pada frasa hanya petani (contoh (35)) dan bukan sopir (contoh (36)), nomina petani dan sopir masing-masing sebagai inti, sedangkan adverbia hanya dan bukan masing-masing sebagai pewatas. Demikian juga juga frasa cuma Budi (contoh (37)), nomina Budi sebagai inti dan adverbia cuma sebagai pewatas.

Perilaku adverbia pewatas nomina dilihat dari segi letak strukturnya selalu mendahului kata yang diterangkan. Jadi, adverbia pewatas nomina tidak bisa terletak di belakang atau mengikuti kata yang diterangkan. Kalau diletakkan di belakang kata yang diterangkan, maka bentuk itu bukan merupakan bentuk yang terterima. Perhatikan contohcontoh berikut.

(38) a. hanya Rini

b. * Rini hanya

(39) a. bukan hantu

b. * hantu bukan

(40) a. cuma sepatu

b. * sepatu cuma

Selain mempunyai perilaku seperti tersebut di atas, adverbia pewatas nomina juga mempunyai perilaku ada yang bisa digunakan sebagai jawaban singkat atas suatu pertanyaan dan ada yang tidak bisa. Perhatikan contoh berikut.

(41) a. Apakah yang datang hanya Tuti ?

$$
\text { b. * Hanya. }
$$

(42) a. Apakah yang lewat itu bukan Roy?

b. Bukan.

(43) a. Apa yang kamu bawa cuma sepatu?

b. * Cuma.

\section{Adverbia Pewatas Numeralia}

Adverbia pewatas numeralia adalah adverbia yang berfungsi sebagai pewatas numeralia. Jadi, dalam sebuah konstruksi frasa yang mengandung nuleralia dan adverbia maka numeralia itu sebagai intinya dan adverbia sebagai pewatas. Contoh-contoh berikut akan menjelaskan hal itu. 
(44) Istrinya memang dua.

(45) Pacar saya hanya satu.

(46) Mobilnya mungkin sepuluh.

Pada frasa memang dua (contoh (44)) dan hanya satu (contoh (45)), numeralia dua dan satu masing-masing sebagai inti, sedangkan adverbia memang dan hanya masing-masing sebagai pewatas. Begitu juga pada frasa mungkin sepuluh (contoh (46)), numeralia sepuluh sebagai inti dan adverbia mungkin sebagai pewatas.

Dari segi letak strukturnya dapat diamati perilaku adverbia pewatas numeralia yang selalu mendahului kata yang diterangkan. Apabila adverbia pewatas numeralia diletakkan di belakang kata yang diterangkan, maka bentuk itu bukan merupakan bentuk yang terterima. Perhatikan contoh berikut.

(47) a. memang dua

b. * dua memang

(48) a. hanya satu

b. * satu hanya

(49) a. mungkin sepuluh

b. * sepuluh mungkin

Selain mempunyai perilaku seperti tersebut di atas, adverbia pewatas numeralia juga berperilaku ada yang dapat digunakan sebagai jawaban singkat atas suatu pertanyaan dan ada juga yang tidak. Lihatlah contoh berikut.

(50) a. Apakah adiknya memang lima?

b. Memang.

(51) a. Apakah pacarnya hanya satu?

b. *Hanya.

\section{Simpulan}

Dari keseluruhan pembahasan di atas dapat ditarik simpulan bahwa jenis adverbia pewatas dalam bahasa Indonesia bukan hanya dua - seperti dinyatakan dalam Tata Bahasa Buku Bahasa Indonesia (1993) —, melainkan empat. Keempat jenis adverbia pewatas itu adalah adverbia pewatas verba, adverbia pewatas adjektiva, adverbia pewatas nomina, dan adverbia pewatas numeralia. Meskipun dalam pembahasan dapat dilihat adanya adverbia pewatas yang dapat dipakai lebih dari satu jenis, namun hal itu 
tidak akan melemahkan deskripsi yang telah diperoleh.

\section{Daftar Pustaka}

Alwi, Hasan (Ed.). 1993. Tata Bahasa Baku Bahasa Kedua. Jakarta : Departemen Pendidikan dan Kebudayaan Republik Indonesia.

Kentjono, Djoko (Ed.). 1982. Dasar-Dasar Linguistik Umum. Jakarta : Fakultas Sastra Universitas Indonesia.

Kridalaksana, Harimurti. 1983. Kamus Linguistik. Jakarta : PT. Gramedia. 1986. Kelas Kata dalam Bahasa Indonesia. Jakarta: PT. Gramedia

Keraf, Gorys. 1984. Tata Bahasa Indonesia. Ende-Flores : Nusa Indah.

Moeliono, Anton M. (Ed.). 1988. Tata Bahasa Buku Bahasa Indonesia. Jakarta : Balai Pustaka.

Ramlan, M. 1985. Ilmu Bahasa Indonesia : Morfologi. Yogyakarta : CV Karyono.

.......... 1985. Tata Bahasa Indonesia : Penggolongan Kata. Yogyakarta : Andi Offset.

.......... 1987. Ilmu Bahasa Indonesia : Sintaksis. Yogyakarta : CV. Karyono

Surono. 1990. Sintaksis : Kata, Frasa, dan Klausa. Semarang : Fakultas Sastra Universitas Diponegoro.

Sudaryanto (Ed.). 1991. Tata Bahasa Baku Bahasa Jawa. Yogyakarta : Duta Wacana University Press. 